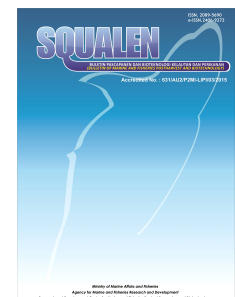

\title{
Detection of Histamine-Producing Bacteria on Tuna Species using Histidine Decarboxylase (hdc) and 16S rRNA
}

\author{
Mala Nurilmala1* ${ }^{*}$, Novia Nanda Saputri ${ }^{1}$, Asadatun Abdullah ${ }^{1}$, Nurjanah Nurjanah ${ }^{1}$, Roza Yusfiandayani ${ }^{2}$, and \\ Muhammad Fedi Alfiadi Sondita ${ }^{2}$ \\ ${ }^{1}$ Department of Aquatic Product Technology, Faculty of Fisheries and Marine Science, Bogor Agricultural University \\ (IPB University), Jl. Raya Dramaga, Kampus IPB Dramaga, Bogor,16680, Indonesia \\ ${ }^{2}$ Department of Fisheries Resources Utilization, Faculty of Fisheries and Marine Science, \\ Bogor Agricultural University (IPB University), Jl. Raya Dramaga, Kampus IPB Dramaga, Bogor, 16680, Indonesia \\ Article history: \\ Received: 22 February 2020; Revised: 27 July 2020; Accepted: 9 November 2020
}

\begin{abstract}
Histamine-producing bacteria to predict histamine level production can be identified by a molecular approach. The purpose of this study was to identify the types of histamine-producing bacteria on tuna, little tuna, and skipjack (TTC) meat, to analyze its bioinformatics through phylogenetic tree construction also to determine the levels of its histamine. The identification of histamine-producing bacteria was conducted using a molecular technique based on the $h d c$ and 16S rRNA genes. Histamine levels were measured by a spectrofluorometer. The results showed types of histamine-producing bacteria had been successfully identified, both using specific hdc and 16S rRNA universal primers, including Morganella morganii, Enterobacter hormaechei, Klebsiella aerogenes, and Enterobacter bugandensis. The phylogenetic tree showed that the bacteria $M$. morganii and $E$. hormaechei were closely related to one cluster. Meanwhile, the other close relative cluster were Klebsiella aerogenes, Enterobacter bugandensis, and Escherichia fergusonii. In addition, histamine levels of frozen tuna, little tuna, and skipjack were $2.96 \pm 0.22$ ppm, $2.14 \pm 0.23 \mathrm{ppm}$, and $1.02 \pm 0.97 \mathrm{ppm}$, respectively.
\end{abstract}

Keywords: histamine-producing bacteria, hdc, 16S rRNA, PCR, tuna

\section{Introduction}

Indonesian fisheries have several superior commodities such as tuna, little tuna, and skipjack (also locally known as Tuna Tongkol Cakalang (TTC) group ) that are the second-largest commodity after shrimp based on the export value. The TTC contributed 713.9 million USD to the export value in 2018 , hence is considered to provide $14.69 \%$ of the marine and fishery exported products (BPS, 2019). Nevertheless, the fish consumption per year in Indonesia was still relatively low compared to other countries, amounting to $47.34 \mathrm{~kg} / \mathrm{cap} /$ year in 2017 (KKP, 2019).

The tuna group is easy to deteriorate by autooxidation (Nurilmala \& Ochiai, 2016; (Nurilmala, Ushio, Watabe, \& Ochiai, 2018) due to high myoglobin content (Nurilmala, Hedeki, Kaneko, \& Ochiai, 2013). Based on the Import Refusal Report (IRR) system data, there were 246 tuna product rejections out of
1,457 Indonesian fishery product cases in 2018 at the American market. The rejections of Indonesian tuna also occurred in the European Union (33 cases), Canada (72 cases), and Japan markets (12 cases). Generally, the rejection of fishery products, especially tuna, little tuna, and skipjack commodities, is caused by the histamine level of the product that exceeds the quality standards of the importing country (Loi \& Gamarro, 2018).

Histamine or [2-(4-imidazolyl) ethylamine] is a biogenic compound of amine formed from the decarboxylation process of free histidine ( $\alpha$-amine- $\beta$ propionic acid inidosal). Endogenous histamine has a physiological role in the human body. However, too much histamine $(100 \mathrm{mg} / 100 \mathrm{~g})$ in food, specifically through fish consumption, leads to histamine fish poisoning (FAO/WHO, 2013). The formation of histamine is strongly influenced by several factors, including the technique, temperature, and time used

${ }^{*}$ Corresponding author.

E-mail: malanm28@yahoo.com 
to catch, handle, and store fish. The critical temperature for histamine formation in fish established by the Food and Drug Administration (FDA) is $4.4^{\circ} \mathrm{C}$ (Caballero, Finglas, \& Toldra, 2016). Histamine levels in fish can be measured by instrumental methods such as high-performance liquid chromatography (HPLC) and spectrofluorometer. However, early detection of histamine is needed. Thus, the early detection of histamine has been developed by detecting the bacteria producing histidine decarboxylase enzyme ( $h d c)$. Detection of histamineproducing bacteria can be done by molecular technique-based on genetic methods such as the polymerase chain reaction (PCR) technique for amplifying DNA (Vidic, Manzano, Chang, \& JaffrezicRenault, 2017). In this case, the target DNA is in the $h d c$ gene as an encoder for the decarboxylaseproducing histidine bacteria.

Identification of decarboxylase-producing histidine bacteria can be done through DNA sequence analysis using the DNA sequence-specific of the $h d c$-producing bacteria (Wongsariya, Bunyapraphatsara, \& Yasawong, 2016). Furthermore, Janda and Abbot (2007) reported that the $16 \mathrm{~S}$ rRNA sequence is very commonly used to analyze the DNA of a microorganism due to the length of the base up to $1500 \mathrm{bp}$. The identification of the types of bacteria using molecular techniques is considered to have high accuracy. Therefore, the purposes of this study were to detect histamine-producing bacteria through the $h d c$ gene encoding histidine decarboxylase and 16S rRNA in tuna, little tuna, and skipjack, then to construct a phylogenetic tree based on the resulted sequences, as well as to detect the level of histamine in the investigated tuna species.

\section{Material and Methods}

\subsection{Material}

Tuna (Thunnus tonggo), little tuna (Euthynnus affinis), and skipjack (Katsuwonus pelamis) were collected from Binuangen Waters, Banten, Indonesia. Fish samples were transported on ice to BogorIndonesia using a cool box with a temperature of $\pm 10^{\circ} \mathrm{C}$ for $8 \mathrm{~h}$, then stored in our laboratory with a temperature of $-18 \pm 2^{\circ} \mathrm{C}$ for one month. Selected tuna fish (Thunnus tonggol) as a positive control was prepared at room temperature $\left(30 \pm 2^{\circ} \mathrm{C}\right)$ for \pm 7 days.

The chemicals used in the study were analytical grade reagents, i.e., DNA TIANamp Genomic DNA Kit (TianGen Biotech, Beijing), agarose (SeaKem®LE Agarose, Lonza, Rockland, ME USA), buffer TBE 10x (AccuGENETM 10XTBE Buffer, Lonza, Rockland, ME USA), GeneRuler 1kb DNA Ladder (Thermo Fisher
Scientific, Vilnius, Lithuania), sybr green, loading dye, kit PCR (VIVANTIS, Selangor Darul Ehsan, Malaysia), lactose broth (DifcoTM, Becton, Dickinson, and Company USA), and anion resin Dowex 1-X8, 50100 mesh (Sigma-Aldrich, Co. St. Louis, MO, USA). Some utilized instruments were PCR machine (Jena Analytik, Germany), electrophoresis (Scie-Plas, UK), vortex (Biosan, Latvia), homogenizer (Nissei Ace, China), UV Transilluminator (Uvitec, Cambridge, England), water bath (F-ScientificLabs, Indonesia), microwaves (Sharp, Osaka, Japan), and spectrofluorometer (Agilent Cary Eclipse, United States).

\subsection{Methods}

\subsubsection{Sample preparation}

The frozen tuna, little tuna, and skipjack were thawed overnight at a chilling temperature $\left( \pm 10^{\circ} \mathrm{C}\right)$. Fish meat samples were carried out without cultivation/enrichment, meanwhile bacterial biomass was obtained by cultivation/enrichment. The fish that treated without cultivation were tuna (BN), little tuna (TN), skipjack (CN), and positive control (PN). While the bacterial biomass obtained through enrichment were tuna meat ( $B E)$, little tuna (TE), skipjack (CE), and positive control (PE).

\subsubsection{Bacteria cultivation method}

The tuna, little tuna, skipjack, and a positive control were weighed about $2 \mathrm{~g}$, then homogenized using a mortar. The sample was then placed in a 250 $\mathrm{mL}$ erlenmeyer flask containing $50 \mathrm{~mL}$ of Lactose Broth (LB) media, incubated at $37^{\circ} \mathrm{C}$ for $16 \mathrm{~h}$, and further isolation of histamine-producing bacteria candidates were carried out based on previous method (Takahashi, et al, 2003). Pure isolate of histamineproducing bacteria in the broth was centrifuged at 11,000 rpm for 4 mins (Nurilmala et al, 2019). The resulting supernatant was removed until bacterial biomass was obtained.

\subsubsection{DNA isolation}

The isolation of DNA in fish meat samples and its bacterial biomass was carried out using a commercial kit, the TIANamp Genomic DNA Kit (TianGen 2016). The $15-25 \mathrm{mg}$ of each fish meat and bacterial biomass samples were transferred to microtube for further isolation following applicable protocols. DNA isolates from $\mathrm{BN}, \mathrm{CN}, \mathrm{TN}, \mathrm{PN}, \mathrm{BE}$, $\mathrm{CE}, \mathrm{TE}$, and PE samples were further analyzed qualitatively using electrophoresis and quantitative analysis by measuring the purity and concentration of DNA (Fatchiyah, Arumingtyas, Widyarti, \& Rahayu, 2011). 


\subsubsection{DNA amplification}

The DNA amplification was carried out using a PCR machine. The target genes were $h d c$ and 16 S rRNA. Specific primers used were forward hdc primer (5'TCHATYARYAACTGYGGTGACTGGRG-3') and reverse hdc primer (5'-CCCACAKCAT BARWG GDGTRTGRCC-3') at a base length of $709 \mathrm{bp}$ (Takahashi, Kimaru, Yoshikawa, \& Fujii, 2003). The universal primers $16 \mathrm{~S}$ rRNAs used were $27 \mathrm{~F}$ (5'AGAGTTGA TCATGGCTCGA-3') and 494R (5'GGCTACCTT GTTACGACTT-3') (Weisburg, Barns, Pelletier, \& Lane, 1991). Each PCR tube contained the following reaction mixture: $12.5 \mu \mathrm{L}$ of taq polymerase $(2.5 \mathrm{U}), 1 \mu \mathrm{L}$ of $20 \mathrm{pmol} / \mu \mathrm{L}$ of each primer, $2 \mu \mathrm{l}$ of isolated DNA, and $8.5 \mu \mathrm{L}$ of sterile water up to a volume of $25 \mu \mathrm{l}$.

PCR conditions for $h d c$-specific primers were $94^{\circ} \mathrm{C}$, 5 mins for initial denaturation; $94^{\circ} \mathrm{C}, 1 \mathrm{~min}$ for denaturation; $60^{\circ} \mathrm{C}, 1 \mathrm{~min}$ for annealing; $70^{\circ} \mathrm{C}, 1$ minute for extension; and $72^{\circ} \mathrm{C}, 1 \mathrm{~min}$ for the final extension with 35 cycles. The PCR conditions for $16 S$ rRNA universal primers were $95^{\circ} \mathrm{C}, 5$ mins initial denaturation; $95^{\circ} \mathrm{C}, 1 \mathrm{~min}$ denaturation; $55^{\circ} \mathrm{C}, 1 \mathrm{~min}$ annealing; $72^{\circ} \mathrm{C}, 2$ mins extension; and $72^{\circ} \mathrm{C}, 10 \mathrm{mins}$ for the final extension with 35 cycles followed the method of Nurilmala and Ochiai (2016) with slight modification. The PCR products were visualized by electrophoresis with the DNA ladder of VC $100 \mathrm{bp}$ plus (100-3,000 bp) from Vivantis, Malaysia. The sequencing was carried out by sending the PCR products directly to First Base (Malaysia).

\subsubsection{Phylogenetic analysis}

The sequencing results were then analyzed by bioinformatics approach using the MEGA 6 (Molecular Evolutionary Genetics Analysis) program. The program was used for the reading and alignment of nucleotide bases. The alignment data was then matched with available data at GenBank at the National Center for Biotechnology Information (NCBI) using the Basic Local Alignment Search Tool (BLAST). The identification and similarity of the species were arranged by examining the homology of the sequence of nucleotide bases (Tamura, Stecher, Peterson, Filipski, \& Kumar, 2013). Therefore, the phylogenetic tree was then constructed by the Neighbor-Joining method with a bootstrap value of 1,000 .

\subsubsection{Histamine analysis}

The samples of frozen tuna, little tuna, skipjack meat, and positive control were analyzed for histamine levels with a spectrofluorometer, according to SNI 2354.10:2009 (BSN 2009). About $10 \mathrm{~g}$ of thawed fish meat were weighed, then added $50 \mathrm{~mL}$ of methanol and homogenized. The samples were then incubated using a water bath shaker for 15 mins at $60^{\circ} \mathrm{C}$, then cooled at room temperature. The samples were then poured into a $100 \mathrm{~mL}$ measuring flask; then, methanol was added to the pitch mark, homogenized, and filtered. The sample solutions and standard histamine dihydrochloride (Sigma-Aldrich, Co. St. Louis, MO, USA) with the concentrations of $0.025 ; 0.050 ; 0.100$; 0.200 dan $0.400 \mathrm{ppm}$ were added $3 \mathrm{~mL} \mathrm{NaOH} 1 \mathrm{~N}, 1$ $\mathrm{mL}$ of $0.1 \% \mathrm{OPT}$, and $\mathrm{H}_{3} \mathrm{PO}_{4} 3.57 \mathrm{~N}$. The samples were measured using a spectrofluorometer at an excitation wavelength of $350 \mathrm{~nm}$ and emission of 444 $\mathrm{nm}$. The anion resin was used to remove impurities before measurement.

\section{Results and Discussion}

\subsection{Histidine Decarboxylase ( $h d c$ ) Coding Gene}

The first step of DNA analysis was DNA isolation. DNA isolation is a process of separating DNA from impurities such as proteins, RNA, and others.

The tuna, little tuna, skipjack, and positive control meat samples from cultivation methods were successfully isolated. However, the results on tuna, little tuna, and skipjack without cultivation appeared smearing on the DNA band (electropherogram is not shown). The smearing of DNA band might be caused by undergoing process of DNA degradation due to the presence of nuclear enzymes (Fatchiyah et al., 2011). The smear can also be caused by the results of the isolation of pure DNA or other materials, the residues of the solutions used during the isolation process, also the isolation of secondary metabolites (Mulyani, Purwanto, \& Nurruhwati, 2011).

The DNA concentration of tuna, little tuna, and skipjack samples using the cultivation method was in the range of $22.7-42.1 \mathrm{ng} / \mathrm{\mu L}$ with a DNA purity of 1.48-2.09. In comparison, the DNA concentration of positive control was $318.0 \mathrm{ng} / \mu \mathrm{L}$ with a DNA purity of 1.95. Meanwhile, the DNA concentration of the three fish samples without the cultivation method was in the range of $55.7-103.9 \mathrm{ng} / \mu \mathrm{L}$ with DNA purity of 2.002.05, while the positive control was $9.8 \mathrm{ng} / \mu \mathrm{L}$ with DNA purity of 1.97. Based on the ratio of the two absorbance values $\left(\AA_{260} / \AA_{280}\right)$ of 1.8-2.0, these DNA concentrations were categorized as good results. The ratio that less than 1.8 indicates isolated DNA was contaminated with proteins or impurities in the solution. On the other hand, the DNA samples were considered as contaminated with the RNA when the ratio is greater than 2.0 (Fatchiyah et al., 2011). 
The modest levels of histamine in tuna, little tuna, and skipjack might complicate the DNA isolation process of the hdc gene. This was proven by the undetected of DNA bands in tuna, little tuna, and skipjack tuna meat samples without the cultivation treatment. The cultivation was carried out on tuna, little tuna, and skipjack samples to grow bacteria, improving bacterial biomass.

The 16S rRNA primers were used as universal primers; meanwhile, the hdc primers were acted as the species-specific primers. Electropherogram of DNA amplification of tuna, little tuna, and skipjack and positive and negative controls using both hdc specific primers and $16 \mathrm{~S}$ rRNA universal primers are shown in Figure 1.

Electropherogram of DNA amplification of tuna, little tuna, and skipjack, as well as positive and negative controls using the hdc primers, were shown in Figure 1 for (1a) and (1b). Based on Figure 1, the DNA target on all samples was successfully visualized at a base length of $\pm 700 \mathrm{bp}$. However, the tuna, little tuna, and skipjack samples with the non-cultivation method were not successfully visualized. These might be due to degraded DNA, as shown in the smear isolated DNA, or no histamine bacteria detected.

Figure 1 for (2a) and (2b) shows that the target DNA from tuna, little tuna, and skipjack and positive control by cultivation methods and positive control by the non-cultivation method using universal $16 \mathrm{~S}$ rRNA

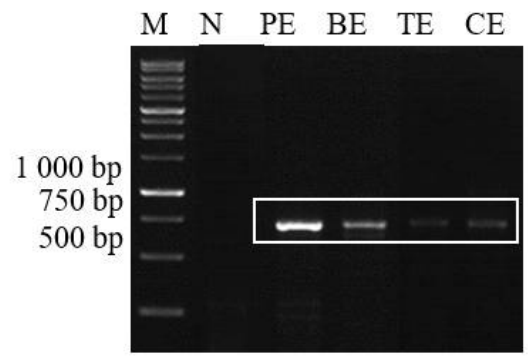

(1a)

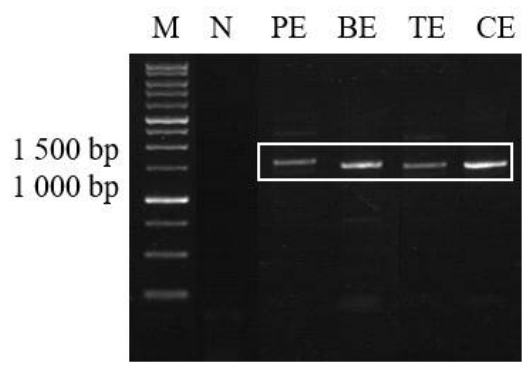

(2a) primers successfully visualized at the base length of $1,500 \mathrm{bp}$. In contrast, the PCR product samples of tuna, little tuna, and skipjack with the non-cultivation method showed no target DNA bands were successfully visualized. This may be due to degraded DNA, as shown in the smear isolated DNA. The lack of visualization in both cultivation and no cultivation method possibly occurred due to either degraded DNA or no histamine bacteria was detected. Cultivation/ enrichment can increase the number of targeted bacteria. Visualization of the target DNA band (single band) in agarose gel proves that the amplification process was successful. The PCR product can be judged of good quality, indicating it could be continued to the sequencing stage.

\subsection{Identification of Histamine-Producing Bacteria}

The amplified PCR product was then sequenced to find out the nucleotide base sequence. The determination of species was carried out by comparing the obtained sequences with the BLAST. The results of species identification are shown in Table 1.

The identification of histamine-producing bacteria by the BLAST analysis showed that the bacterial species identified in each sample differed. Bacteria identified in tuna, little tuna, and positive control samples with cultivation method and positive control without cultivation method using hdc primers was

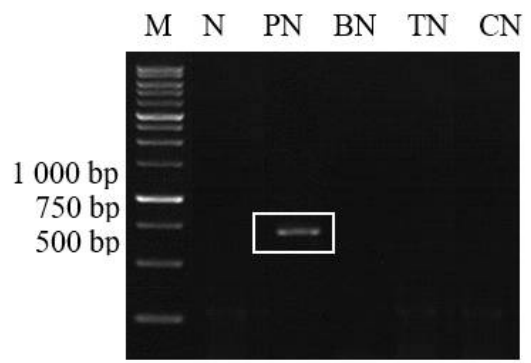

(1b)

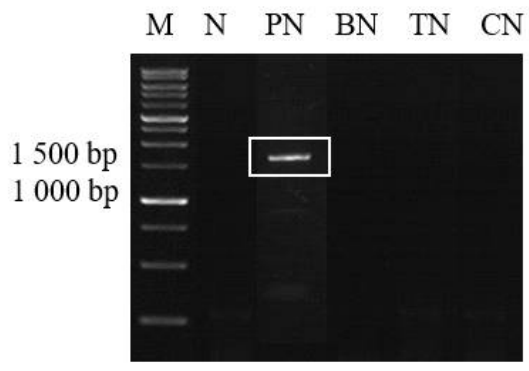

(2b)

Figure 1. DNA amplification of tuna, little tuna, and skipjack samples. (1) hdc, (2) $16 \mathrm{~S}$ rRNA, (a) The bacterial biomass from fish obtained through cultivation/enrichment: positive control (PE), tuna meat ( $B E$ ), little tuna (TE), and skipjack (CE); (b) non-cultivation method, positive control (PN), tuna meat ( $\mathrm{BN})$, little tuna (TN), and skipjack (CN). Marker (M), negative control (N) 
Table 1. The identified histamine-producing bacteria by BLAST analysis

\begin{tabular}{|c|c|c|c|c|}
\hline Sample & Name of organism & $\begin{array}{c}\text { Gram- } \\
\text { negative/positive }\end{array}$ & $\begin{array}{l}\text { Homology } \\
\text { percentages }\end{array}$ & $\begin{array}{l}\text { Accession } \\
\text { number }\end{array}$ \\
\hline \multicolumn{5}{|c|}{ Histidine decarboxylase specific primary (HDC) } \\
\hline $\begin{array}{l}\text { Positive control } \\
\text { non-cultivation } \\
\text { (PN) }\end{array}$ & Morganella morganii & Gram negative $^{1}$ & $98.14 \%$ & CP041655.1 \\
\hline $\begin{array}{l}\text { Positive control } \\
\text { cultivation }(\mathrm{PE})\end{array}$ & Morganella morganii & Gram negative ${ }^{1}$ & $98.20 \%$ & СР041655.1 \\
\hline $\begin{array}{l}\text { Tuna cultivation } \\
\text { (BE) }\end{array}$ & Morganella morganii & Gram negative ${ }^{1}$ & $99.49 \%$ & KC771251.1 \\
\hline $\begin{array}{l}\text { Little tuna } \\
\text { cultivation (TE) }\end{array}$ & Morganella morganii & Gram negative $^{1}$ & $100.00 \%$ & KP728801.1 \\
\hline $\begin{array}{l}\text { Skipjack } \\
\text { cultivation (CE) }\end{array}$ & $\begin{array}{c}\text { Enterobacter } \\
\text { hormaechei }\end{array}$ & Gram negative $^{1}$ & $99.84 \%$ & СР010384.1 \\
\hline \multicolumn{5}{|c|}{ Universal 16S rRNA primary } \\
\hline $\begin{array}{l}\text { Positive control } \\
\text { non-cultivation } \\
\text { (PN) }\end{array}$ & $\begin{array}{l}\text { Vagococcus } \\
\text { carniphilus }\end{array}$ & Gram positive $^{2}$ & $90.88 \%$ & NR_025689.1 \\
\hline $\begin{array}{l}\text { Positive control } \\
\text { cultivation (PE) }\end{array}$ & $\begin{array}{l}\text { Peptoniphilus } \\
\text { stercorisuis }\end{array}$ & Gram positive $^{3}$ & $84.24 \%$ & NR_134130.1 \\
\hline $\begin{array}{l}\text { Tuna cultivation } \\
\text { (BE) }\end{array}$ & $\begin{array}{l}\text { Klebsiella } \\
\text { aerogenes }\end{array}$ & Gram negative $^{1}$ & $99.45 \%$ & NR_102493.2 \\
\hline $\begin{array}{l}\text { Little tuna } \\
\text { cultivation (TE) }\end{array}$ & $\begin{array}{l}\text { Enterobacter } \\
\text { bugandensis }\end{array}$ & Gram negative ${ }^{1}$ & $99.82 \%$ & NR_148649.1 \\
\hline $\begin{array}{l}\text { Skipjack } \\
\text { cultivation (CE) }\end{array}$ & $\begin{array}{l}\text { Escherichia } \\
\text { fergussonii }\end{array}$ & Gram negative ${ }^{1}$ & $99.87 \%$ & NR_074902 \\
\hline
\end{tabular}

Morganella morganii with homology percentages ranging from $98-100 \%$. Moreover, the bacteria in samples skipjack meat with hdc specific primary cultivation method was Enterobacter hormaechei, with a homology percentage of $99.54 \%$. On the other hand, the identified histamine-producing bacteria using universal $16 \mathrm{~S}$ rRNA primers were different compared to those of $h d c$. These probably due to the differences of primer characters. Bacterial species identified in tuna, little tuna, and skipjack, as well as both positive controls by cultivation and non-cultivation method using 16S rRNA universal primers respectively, were $K$. aerogenes, E. bugandensis, and E. fergussonii, $P$. stercorisuis, and $V$. carniphilus with homology percentages ranging from $84-100 \%$.

Histamine-producing bacteria are generally classified in the group of enteric bacteria and mesophilic group. Mesophilic bacteria has optimum temperature to grow at $37^{\circ} \mathrm{C}$, including $M$. morganii, Enterobacter sp.and Hafnia alvei (Bjornsdottir, Bolton, McClellan-Green, Jaykus, \& Green, 2009). Ferrario, Pegollo, Ricci, Borgo, \& Fortina (2012) reported that the bacteria M. morganii and E. hormaechei were identified in the yellowfin tuna (Thunnus albacares) fillet samples with the cultivation method during 8-16 $\mathrm{h}$ incubation at room temperature as the dominant bacteria producing the $h d c$ enzyme also acted as histamine-producing bacteria. Each of these bacteria produced histamine of $210 \mathrm{mg} / 100 \mathrm{~g}$ and $50 \mathrm{mg} / 100 \mathrm{~g}$, respectively (Urs, Ramlal, Batra, Naika, \& Jeyabalaji, 2019). Some histamine-producing bacteria species are also able to live in cold temperatures (up to $0^{\circ} \mathrm{C}$ ) or commonly referred to as psychrotolerant, e.g., Photobacterium phosphoreum (Kanki, Yoda, 
Ishibashi, \& Tsukamoto, 2004) and $M$. psychrotolerans (Emborg, Dalgaard, \& Ahrens, 2006).

In this study, the histamine-producing bacteria identified were $M$. morganii, $E$. bugandensis, $K$. aerogenes, and $E$. hormaechei. The bacteria that produce high histamine are $M$. morganii and Enterobacter sp. Meanwhile, the group of bacteria that produce low histamine are $\mathrm{H}$. alvei and Citrobacter freundii. Furthermore, nonhistamine producer bacteria is Escherichia sp. (Bjornsdottir et al., 2009). Histamine could be formed and induced by both Gram-negative and Gram-positive bacteria. Gram-negative bacteria such as $K$. planticola and $E$. aerogenes are able to synthesize the pyridoxal-5'-phosphate (PLP) -dependent enzyme (Kamath, Vaaler, \& Snell, 1991). Histamine-producing Gram-positive bacteria are generally classified in the genus Clostridium, Micrococcus, Lactobacillus, Leuconostoc, and Tetragenococcus. While, $P$. stercorisuis and $V$. carniphilus are categorized as nonhistamine-producing Gram-positive bacteria.

\subsection{Phylogenetic Tree}

Bacteria produced by tuna, little tuna, and skipjack were aligned with the ingroup of each bacterial species and out of the groups, i.e. Staphylococcus saprophyticus. The phylogenetic tree of Figure 2 shows that $M$. morganii bacteria of tuna (BE), little tuna (TE), and positive control (PE) samples with cultivation and positive control (PN) with the non-cultivation formed groups on one branch with short branch spacing with M. morganii species ingroup and bootstrap values of $100 \%$. E. hormaechei bacteria of skipjack tuna samples by cultivation formed groups in one branch with ingroups of $E$. hormaechei with bootstrap values of $100 \%$. The phylogenetic tree presented in Figure 2 shows that $M$. morganii and $E$. hormaechei have a close kinship where both species are in the same branch and have a distant kinship with the species $S$. saprophyticus.

The phylogenetic in Figure 3 indicates that $K$. aerogenes bacteria of tuna (BE) samples by cultivation formed a group in one branch in the $K$. aerogenes species group with a bootstrap value of $64 \%$. E. bugandensis bacteria samples of little tuna with cultivation methods formed a group in one branch in the $E$. bugandensis species group with a bootstrap value of $64 \%$. E. fergusonii bacteria samples of skipjack by cultivation method formed a group in one branch in the group of $E$. fergusonii species with a

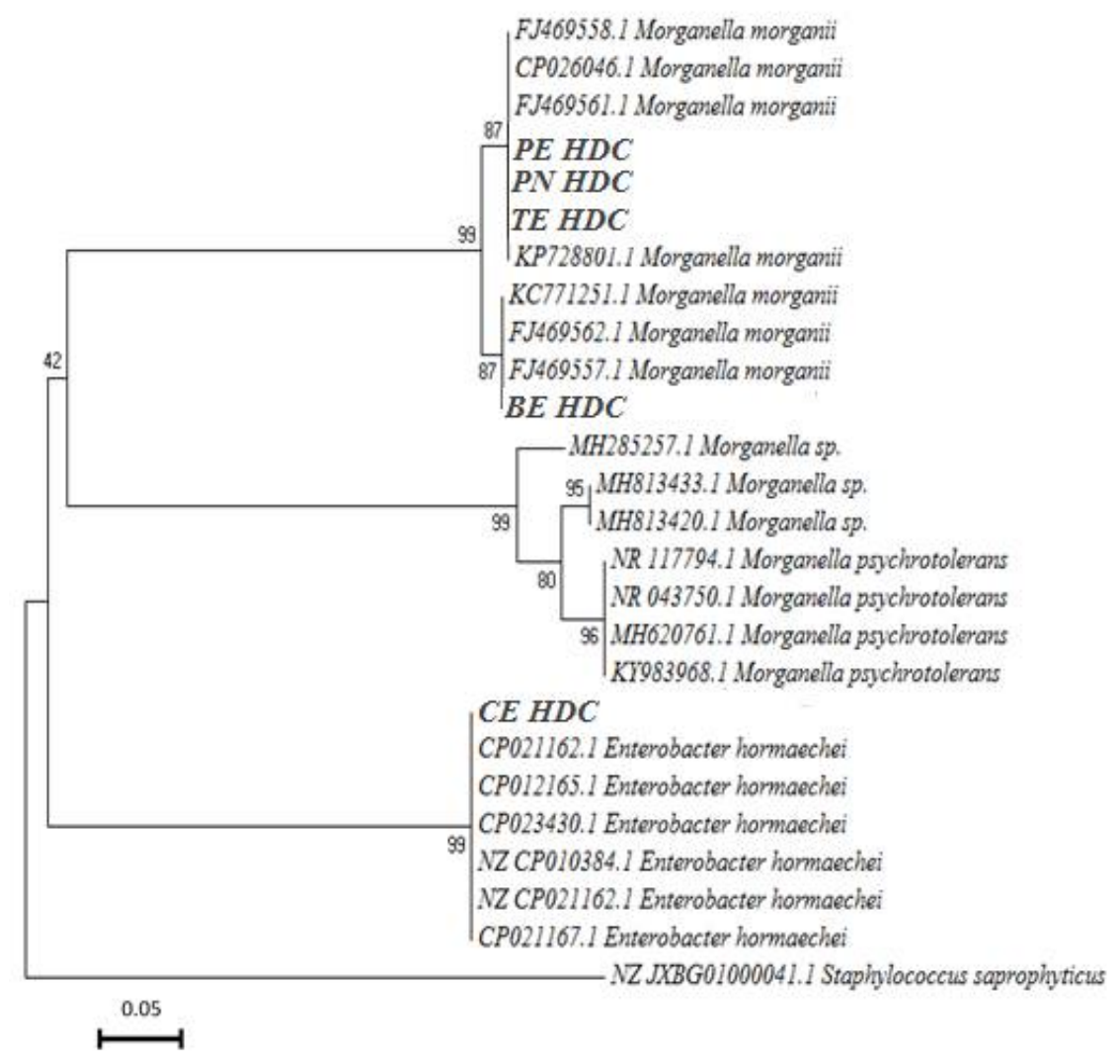

Figure 2. The phylogenetic tree using the primary $h d c$-specific gene of histamine-producing bacteria isolated from tuna, little tuna and skipjack (Note: codes printed in bold represent samples isolated from this study) 


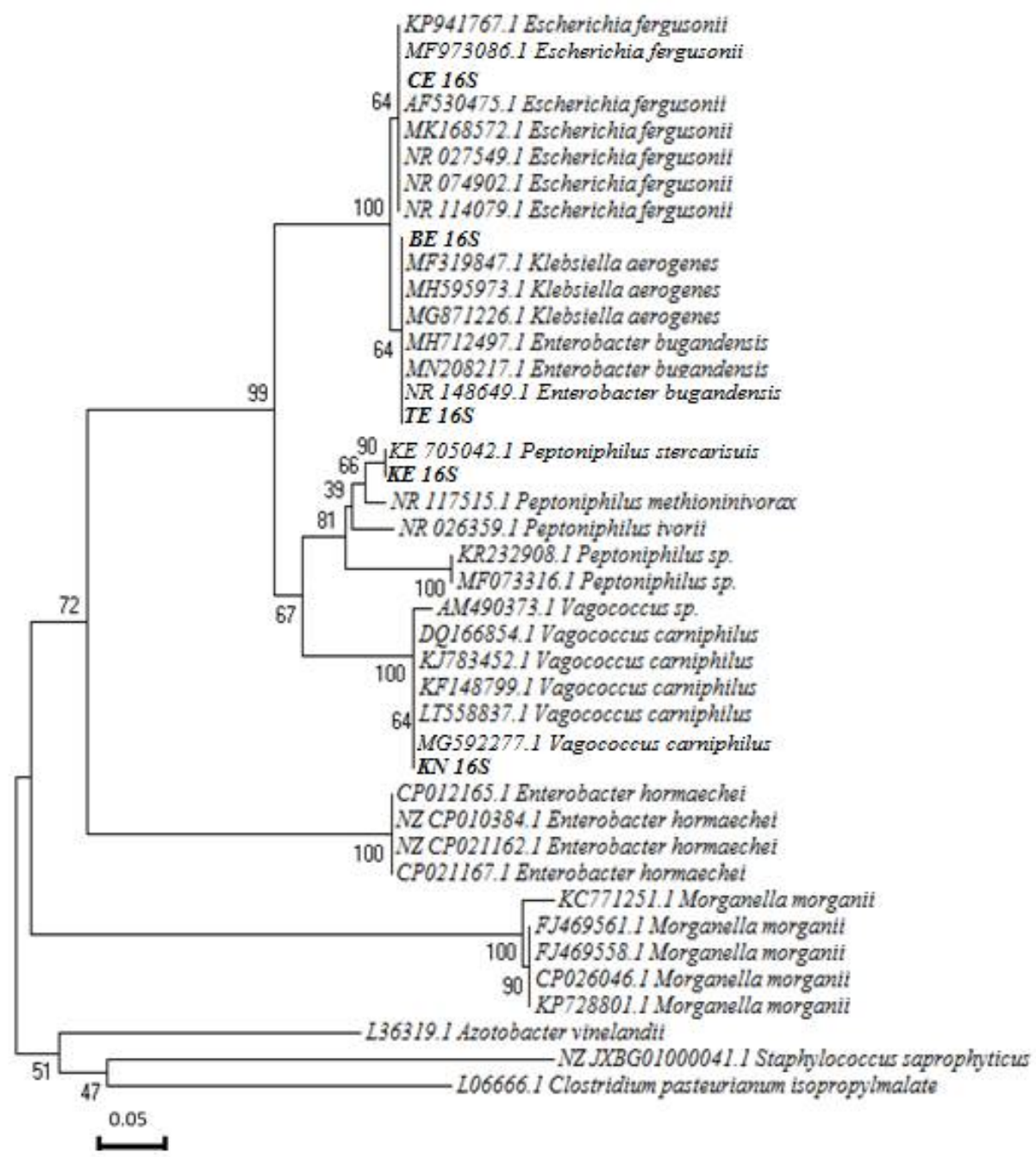

Figure 3. The phylogenetic tree using the $16 \mathrm{~S}$ rRNA universal primary gene of histamine-producing bacteria isolated from tuna, little tuna and skipjack (Note: codes printed in bold represent samples isolated from this study)

bootstrap value of $68 \%$. P. stercorisuis bacterium of positive control fish samples using the cultivation method formed a group in one branch in the $P$. stercorisuis species group with a bootstrap value of $99 \%$. V. carniphilus bacteria positive control fish samples by the method without cultivation formed a group in one branch in the group $V$. carniphilus species with a bootstrap value of $100 \%$.

Figure 3 shows the species of $K$. aerogenes, $E$. bugandensis, and $E$. fergusonii have close relatives. Bacteria $K$. aerogenes, $E$. bugandensis, and $E$. fergusonii belong to the Gram-negative group, while $P$. stercorisuis and $V$. carniphilus are included in the Gram-positive group. Branches formed in the phylogenetic tree indicate the degree of kinship. The closer the tree branch means the level of kinship is also getting closer. The study by Takahashi, Kimaru, Yoshikawa, \& Fujii (2003) showed the phylogenic tree construction of 14 strains of histamine-producing bacteria, M. morganii, Raoultella planticola, Erwinia sp., and $E$. aerogenes in the same branch, and separated from the branches of the bacteria Photobacterium phosphoreum and Photobacterium damselae.

\subsection{Histamine Analysis}

The histamine levels in tuna, little tuna, and skipjack tuna meat are presented in Table 2. Based on the detected histamine levels ranged from 1.02 to 2.96 ppm; tuna, little tuna, and skipjack meat were considered safe for consumption since they do not exceed the maximum standard for histamine levels. The maximum standard value for histamine in Indonesia according to SNI 2729: 2013 (BSN, 2013) is 100 ppm, whereas the maximum levels of histamine in the European Union according to EC No. 2074/2005 as well as in America and Canada are 100 and 50 ppm, respectively (Caballero, et al., 2016). 
Tabel 2. Tuna, little tuna, and skipjack histamine levels

\begin{tabular}{lc}
\hline \multicolumn{1}{c}{ Sample } & Histamine levels $(\mathbf{p p m})$ \\
\hline Tuna & $2.96 \pm 0.22$ \\
Little tuna & $2.14 \pm 0.23$ \\
Skipjack & $1.02 \pm 0.97$ \\
Positive control & $755.86 \pm 0.09$ \\
\hline
\end{tabular}

Previous studies have reported the presence of free histidine in tuna, little tuna, and skipjack of $1,220 \mathrm{mg} /$ $\mathrm{kg}, 1,340 \mathrm{mg} / \mathrm{kg}$, and $1,090 \mathrm{mg} / \mathrm{kg}$ respectively, (Suyama \& Yoshizawa, 1973). High levels of free histidine affect histamine levels in tuna, little tuna, and skipjack. The higher the free histidine level, the higher the histamine compound that will be formed.

The standard storage procedures for exporting fish such as tuna, little tuna, and skipjack are at low temperatures. Verkhivker and Altman (2018), who examined histamine levels in frozen Scrombidae group stored for 10 months, stated that the histamine levels increased in the first four months and reached a maximum level after six months of storage and decreased in the $8^{\text {th }}$ to $10^{\text {th }}$ month of storage. The presence of bacteria in fish meat can convert histamine into its derivative compounds.

The thawing method is considered efficient to influence histamine levels in fish meat. As stated by llyasa (2018), histamine levels of fish meat with the thawing treatment in chilling temperature $\left( \pm 10^{\circ} \mathrm{C}\right)$ were the lowest $(<8 \mathrm{ppm})$, compared to those of room temperature thawing $\left( \pm 27^{\circ} \mathrm{C}\right)$ and running water. Thawing with chilling temperature $\left( \pm 10^{\circ} \mathrm{C}\right)$ is the best method to handle fish compared to thawing with room temperature and running water. This is probably because the low ambient temperatures during thawing delayed the reproduction of histamine-bacteria up to $17 \mathrm{~h}$.

In this study, a molecular approach using specific $h d c$ and 16 S rRNA universal could detect histamineproducing bacteria with lactose broth as cultivation/ enrichment media. However, the levels of histamine in these fish were low. Therefore, this approach is the best method to detect earlier presence of histamine.

\section{Conclusions}

The histamine-producing bacteria have been successfully isolated and identified in tuna, little tuna, and skipjack using specific $h d c$ and $16 \mathrm{~S}$ rRNA universal primers. These bacteria are $M$. morganii, $E$. hormaechei, K. aerogenes, and E. bugandensis. The histamine levels of tuna, little tuna, and skipjack in this study were $2.96 \pm 0.22 \mathrm{ppm}, 2.14 \pm 0.23 \mathrm{ppm}$, and $1.02 \pm 0.97 \mathrm{ppm}$, respectively. The different primers, as well as different genes, will be provided for further study.

\section{Acknowledgments}

The authors acknowledge EMBRIO International Workshop 2020 and EMBRIO-IPB team for contributing in this study.

\section{References}

Badan Pusat Statistik. (BPS) (2019). Angka konsumsi ikan target 2018-2019. Jakarta, ID: Direktorat Jendral Penguatan Daya Saing Produk Kelautan dan Perikanan.

Badan Standarisasi Nasional. (BSN) (2009). Cara Uji Kimia- Bagian 10: Penentuan Kadar Histamin dengan Spektroflorometri dan Kromatografi Cair Kinerja Tinggi (KCKT) pada Produk Perikanan. SNI 2354.10:2009. Jakarta, ID: Badan Standarisasi Nasional.

Badan Standarisasi Nasional. (BSN) (2013). Ikan Segar. SNI 2729:2013. Jakarta, ID: Badan Standarisasi Nasional.

Bjornsdottir K., Bolton, G. E., McClellan-Green, P. D., Jaykus, L. A., \& Green, D. P. (2009). Detection of Gramnegative histamine-producing bacteria in fish: a comparative study. Journal of Food Protection, 72(9), 1987-1991. doi: 10.4315/0362-028X-72.9.1987.

Caballero, B., Finglas, P. M., Toldra, F. (2016). Encyclopedia of food and Health. (pp. 287-300). United Kingdom, GB: Academic Press.

Emborg, J., Dalgaard, P., \& Ahrens, P. (2006). Morganella psychrotolerans sp. nov., a histamine producing bacterium isolated from various seafoods. International Journal of Systematic and Evolutionary Microbiology, 56(10), 2473-2479. doi: 10.1099/ ijs. 0.64357-0.

Food and Agriculture Organization of the United Nations/ World Health Organization. (FAO/WHO) (2013). Public health risks of histamine and other biogenic amines from fish and fishery products. Italia, IT: Meeting Report.

Fatchiyah, Arumingtyas, E.S., Widyarti, S., \& Rahayu, S. (2011). Biologi molekuler prinsip dasar analisis. (pp. 10-55). Jakarta, ID: Penerbit Erlangga. 
Ferrario, C., Pegollo, C., Ricci, G., Borgo, F., \& Fortina, M. G. (2012). PCR detection and identification of histamine-forming bacteria in filleted tuna fish samples. Journal of Food Science, 77(2), 115-120. doi: 10.1111/j.1750-3841.2011.02535.x.

llyasa, M. (2018). Pengaruh cara thawing pada ikan tuna skipjack (Katsuwonus pelamis) terhadap cooking loss dan kadar histamin. Thesis. IPB University, Indonesia.

Janda, J.M., \& Abbot, S. L. (2007). 16S rRNA gene sequencing for bacterial identification in the diagnostic laboratory: pluses, perils, and pitfalls. Journal of Clinical Microbiology. 45(9), 2761-2764. doi: :10.1128/JCM.01228-07.

Johnson, C. N., Whitehead, T. R., Cotta, M. A., Rhoades, R. E., \& Lawson, P. A. (2014). Peptoniphilus stercorisuis sp. nov., isolated from a swine manure storage tank and description of Peptoniphilaceae fam. nov. International Journal of Systematic and Evaluationary Microbiology, 64(10), 3538-3545. doi:10.1099/ijs.0.058941-0.

Kementrian Kelautan dan Perikanan. (KKP) (2019). Nilai dan volume ekspor tuna, cakalang, tongkol periode Januari-Maret (Triwulan I) tahun 2019. Jakarta, ID: Kementrian Kelautan dan Perikanan.

Kamath, A. V., Vaaler, G. L., \& Snell, E. E. (1991). Pyridoxal phosphate-dependent histidine decarboxylases cloning, sequencing, and expression of genes from Klebsiella planticola and Enterobacter aerogenes and properties of the overexpressed enzymes. Journal of Biological Chemistry, 266(15), 9432-9437.

Kanki, M., Yoda, T., Ishibashi, M., \& Tsukamoto, T. (2004). Photobacterium phosphoreum caused a histamine fish poisoning incident. International Journal of Food Microbiology, 92(1), 79-87. doi:10.1016/ j.ijfoodmicro.2003.08.019.

Kim, S. H., An, H., Field, K. G., Wei, C. I., Velazquez, J. B., Ben-Gigirey, B., Morrissey, M. T., Price, R. J., \& Pitta, T. P. (2003). Detection of Morganella morganii, a prolific histamine former, by the polymerase chain reaction assay with 16S rDNA-targeted primers. Journal of Food Protection, 66(8), 1385-1392.

Loi, G., \& Gamarro, E. G. (2018). Border rejection trends of fishery and aquaculture products in European Union, United States of America and Japan. FAO Aquaculture Newsletter, (58), 44-46.

Mulyani, Y., Purwanto, A., \& Nurruhwati, I. (2011). Perbandingan beberapa metode isolasi DNA untuk deteksi dini koi herpes virus (KHV) pada ikan mas (Cyprinus carpio L.). Jurnal Akuatik, 2(1), 1-16.

Nurilmala, M., Abdullah, A., Matutina, V.M., Nurjanah, Yusfiandayani, R., Sondita, M.F.A., Hizbullah, H.H., 2019. Chemical microbiology changes and detection of hdc gene on longtail tuna Thunnus tonggol during chilling temperature storage. Jurnal IImu dan Teknologi Kelautan Tropis. 11(2), 285-296.

Nurilmala, M., \& Ochiai, Y. (2016). Molecular characterization of southern bluefin tuna myoglobin (Thunnus maccoyii). Fish Physiology and Biochemistry, 42, 1407-1416.
Nurilmala, M., Ushio, U., Watabe, S., \& Ochiai, Y. (2018). A Stream-lined isolation method and the autoxidation profiles of tuna myoglobin. Journal Food Science and Technology, 55, 1641-1647. doi: 10.1007/s13197018-3068-3.

Nurilmala, M, Hedeki, U., Kaneko, G., \& Ochiai, Y. (2013). Assessment of commercial quality evaluation of yellowfin tuna Thunnus albacares meat based on myoglobin properties. Food Science Technology Research, 19, 237-243.

Shewmaker, P. L., Steigerwalt, A. G., Morey, R. E., Carvalho, M. G. S., Elliot, J. A., Joyce, K., Barrett, T. J., Teixeira, L. M., \& Facklam, R. R. (2004). Vagococcus carniphilus sp. nov., isolated from ground beef. International Journal of Systematic and Evaluationary Microbiology, 54(5), 1505-1510. doi: 10.1099/ ijs.0.02908-0.

Suyama, M., \& Yoshizawa, Y. (1973). Free amino acid composition of the skeletal muscle of migratory fish. Bulletin of the Japanese Society of Fish Science, 39, 1339-1343.

Takahashi, H., Kimaru, B., Yoshikawa, M., \& Fujii, T. (2003). Cloning and sequencing of the histidine dekarboksilase genes of Gram-negative, histamineproducing bacteria and their application in detection and identification of these organism in fish. Applied and Environmental Microbiology, 69(5), 2568-2579. doi: 10.1128/AEM.69.5.2568-2579.2003.

Tamura, K., Stecher, G., Peterson, D., Filipski, A., \& Kumar, S. (2013). MEGA6: Molecular evolutionary genetics analysis version 6.0. Molecular Biology and Evolution, 30(12), 2725-2729. doi: 10.1093/molbev/mst197.

TianGen. (2016). TIANamp Genomic DNA Kit. http:// www.tiangen.com/en [23 Juli 2019].

Urs, V. R. S., Ramlal, S., Batra, H. V., Naika, M., \& Jeyabalaji, J. K. (2019). An in-vitro screening for biogenic amines producing microorganisms from fermented foods and its degradation by bacteria from Canine saliva. Journal Pure Application Microbiol, 13(1), 271-280. doi: 10.22207/JPAM.13.1.29.

Verkhivker, Y., \& Altman, E. (2018). Influence parameters of storage on the process of formation the histamine in fish and fish products. Journal of Water Resources and Ocean Science, 7(1), 10-14. doi: 10.11648/ j.wros.20180701.12.

Vidic, J., Manzano, M., Chang, C. M., \& Jaffrezic-Renault, N. (2017). Advanced biosensors for detection of pathogens related to livestock and poultry. Veterinary Research, 48(11), 1-22. doi: 10.1186/s13567-0170418-5.

Weisburg, W. G., Barns, S. M., Pelletier, D. A., \& Lane, D. J. (1991). 16S ribosomal DNA amplification for phylogenetic study. Journal of Bacteriology, 173(2), 697-703. doi: 10.1128/jb.173.2.697-703.1991.

Wongsariya K., Bunyapraphatsara N., \& Yasawong M. (2016). Development of molecular approach based on PCR assay for detection of histamine producing bacteria. Journal of Food Science and Technology, 53, 640-648. doi: 10.1007/s13197-015-1982-1. 